
PKSOI PAPER

\title{
SECURITY SECTOR REFORM IN TIMOR-LESTE: MISSED OPPORTUNITIES AND HARD LESSONS IN EMPOWERING THE HOST-NATION
}

\author{
Nicholas J. Armstrong \\ Jacqueline Chura-Beaver \\ Isaac Kfir
}

April 2012

The views expressed in this report are those of the author and do not necessarily reflect the official policy or position of the Department of the Army, the Department of Defense, or the U.S. Government. Authors of Peacekeeping and Stability Operations Institute (PKSOI) publications enjoy full academic freedom, provided they do not disclose classified information, jeopardize operations security, or misrepresent official U.S. policy. Such academic freedom empowers them to offer new and sometimes controversial perspectives in the interest of furthering debate on key issues. This report is cleared for public release; distribution is unlimited.

$* * * * *$

This publication is subject to Title 17, United States Code, Sections 101 and 105. It is in the public domain and may not be copyrighted. 
Comments pertaining to this report are invited and should be forwarded to: Director, Peacekeeping and Stability Operations Institute, U.S. Army War College, 22 Ashburn Drive, Carlisle, PA 17013-5054.

\begin{abstract}
$* * * * *$
All Peacekeeping and Stability Operations Institute (PKSOI) publications are available on the PKSOI homepage for electronic dissemination. Hard copies of this report also may be ordered while copies last from our homepage. PKSOI's homepage address is: https://pksoi.army.mil

The Peacekeeping and Stability Operations Institute publishes a quarterly journal to update the peace and stability operations community on the research of our analysts, recent and forthcoming publications and upcoming conferences sponsored by PKSOI. Each quarterly journal has a specific theme related to peace and stability operations and a commentary by the Director of PKSOI entitled The Director's Corner. If you are interested in receiving this journal, please subscribe on our homepage at $h t t p: / /$ pksoi.army.mil/subscription.cfm.
\end{abstract}

ISBN: 978-0-9833514-4-3 


\section{FOREWORD}

As the United States and its coalition partners continue with transitions to host-nation civil authorities in both Iraq and Afghanistan, authors Isaac Kfir, Nicholas Armstrong, and Jacqueline Chura-Beaver examine an important case study of the United Nation's transition efforts in Timor-Leste. Unlike Iraq and Afghanistan, Timor-Leste seemed to have favorable conditions for success; yet, after 13 years of UN efforts, Timorese security sector reform has remained elusive. This case study has great implications for our efforts to better understand how fragile, failing, and failed states better transition to resilient self-governance and responsible security partners.

The authors explore the dichotomy for host-nation ownership with the role of foreign assistance in security sector reform. They conclude that this balance is a critical variable that will determine success or failure regardless of the starting condition. Their conclusion serves to highlight the importance of the present U.S. defense strategic guidance, with its emphasis on the promotion of security, prosperity, and human dignity through capacity building engagements.

After a decade of stability operations experience, and faced with today's difficult fiscal choices, our Nation is at a critical decision point in determining its future military strategy. As we continue to institutionalize the hard-earned lessons of the past decade, this monograph highlights the value of deliberate and candid analysis into the complexities and uncertainties inherent in transitions to host-nation civil authority. It is easiest to hope the future will not require operations like Timor-Leste; however, present indications 
are that the exact opposite is true. To inform future plans and preparations, we must continue to seriously examine important past lessons, as our authors have done so well in this monograph.

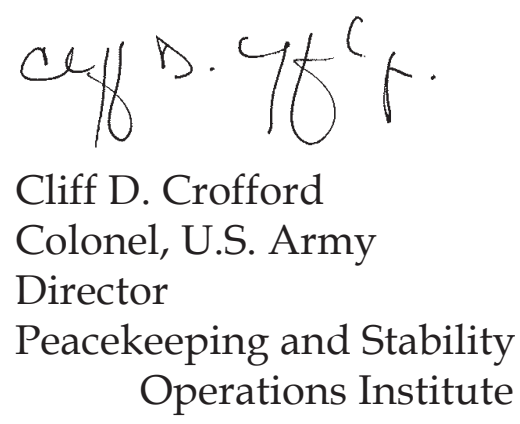




\section{ABOUT THE AUTHOR}

NICHOLAS J. ARMSTRONG is a Research Fellow with the Institute for National Security and Counterterrorism (INSCT) at the Maxwell School of Syracuse University and a Non-Resident Fellow at the U.S. Army's Peacekeeping and Stability Operations Institute (PKSOI). Mr. Armstrong joined INSCT in 2008 after eight years of service as a field artillery officer in the U.S. Army, and subsequently in 2010, he was selected as a Non-Resident Fellow with PKSOI. His previous leadership and staff assignments in the Army include service with the 10th Mountain Division (Light Infantry) as a Company Fire Support Officer, Battery Platoon Leader and Executive Officer, Aide-de-Camp to the Deputy Commanding General, Speechwriter and Special Assistant to the Commanding General, Battalion Fire Support Officer, and Infantry Battalion Assistant S3. Armstrong also served an additional year in the NY Army National Guard as an Assistant Brigade Fire Support Officer. Armstrong is a combat veteran with prior service in Iraq (20052006), Afghanistan (2003-2004) and Bosnia (2001-2002) and a graduate of the U.S. Army Ranger, Airborne and Air Assault Schools. In his current capacity, Mr. Armstrong leads INSCT's program on Postconflict Reconstruction, which includes a graduate certificate program, collaborative research, and an ongoing guest speaker series. Among his research interests are U.S. national security and defense policy, security cooperation and assistance, complex peace and stability operations, defense sector management, and veterans policy. Mr. Armstrong holds degrees from the U.S. Military Academy at West Point (BS) and the Maxwell School of Citizenship and Public Affairs at Syracuse 
University (MPA). In addition to his full-time duties at INSCT, Armstrong is also a PhD Candidate (ABD) in Social Science (International Security Studies) at the Maxwell School. His dissertation focuses on processes of institutional transfer in security force assistance partnerships between U.S./NATO embedded advisors and the Afghan National Security Forces.

MS. JACQUELINE CHURA-BEAVER joined the U.S. Army's Peacekeeping and Stability Operations Institute (PKSOI) Stabilization, Reconstruction, and Transition (STR) division in 2009. Prior to joining PKSOI, she served as an intern and later a Foreign Affairs Officer (FAO) at the U.S. Department of State Bureau of Political-Military Affairs in support of the Global Peace Operations Initiative (GPOI). Jacqueline has undertaken significant research projects on topics including leadership in provincial reconstruction teams (PRTs) in Iraq and Afghanistan, governance issues in fragile states, and successes and failures of the Vietnam-era Civil Organization and Revolutionary Development Support (CORDS) program. She has also conducted extensive research on issues and consequences of transition in stability operations.

Jacqueline holds a Bachelor of Arts in Political Science and Spanish from the University of Dayton (2006); and a Master's in Public and International Affairs, with a concentration in Security and Intelligence Studies, from the University of Pittsburgh Graduate School of Public and International Affairs (2010).

ISAAC KFIR is a Visiting Professor at the College of Law and Maxwell School of Citizenship and Public Affairs at Syracuse University. Isaac is a Research Associate at the Institute for National Security and 
Counterterrorism (INSCT), Syracuse University, and is a Senior Researcher at the International Institute for Counter-Terrorism (ICT), Herzliya, Israel. Isaac was an Assistant Professor at the Interdisciplinary Center (IDC) in Herzliya, Israel for several years.

Prior, he served as a Research Fellow in International Relations at the University of Buckingham. Isaac received his Ph.D. from the London School of Economics (1999) in International Relations and has a Post-Graduate Diploma in Law (PGDL) and the Bar Vocational Certificate from BPP Law School in 2001. He was a member of Inner Temple.

Isaac's research centers on political and conflict transformation in South Asia (primarily in relation to Pakistan and Afghanistan) and the Greater Middle East. He specifically examines issues relating to postconflict reconstruction (security issues) and transitional justice (restorative and retributive justice). He lectures on post-conflict reconstruction and the rule of law; international human rights law; how state and non-state actors combat Islamic terrorism; UN peacekeeping operations in Africa and the Middle East; Islamic radicalism; and democratic theory in relation to developing nations (South Asia and Africa). Isaac has published with Studies in Conflict and Terrorism; Middle East Review of International Affairs; Joint Forces Quarterly, etc. and is currently writing two books, the first focuses on Pakistan and democracy, and the second on post-conflict reconstruction in the twenty-first century. 



\section{SUMMARY}

This monograph builds upon the themes presented in Armstrong and Chura-Beaver's previous works, Harnessing Postconflict Transitions: A Conceptual Primer (2010) and Practitioner Frameworks on the Host-Nation Role in Transition to Determine how Countries Contribute to their Own Security Transitions (2010).

In 1999, the people of East Timor voted, overwhelmingly, against a proposal that would make their island an autonomous province of the Republic of Indonesia. Though it appeared that all of the factors for a successful transition from conflict to peace and stability were present and it was expected that establishing a new state would be fairly straightforward, surprisingly, to the International Community, this was not the case.

This paper examines the United Nation's (UN) efforts in Timor-Leste (formerly East Timor) as an important case for the study of SSR and postconflict stabilization and reconstruction. The authors argue that, despite presumed favorable conditions especially when contrasted against other contemporary peace support operations, the SSR program has failed. The paper begins with a brief history of the UN's efforts at SSR in Timor-Leste and then presents an analytical framework to assess these efforts based on the Guiding Principles for Stabilization and Reconstruction, co-authored by the U.S. Institute of Peace and U.S. Army Peacekeeping and Stability Operations Institute. Using this framework, the paper highlights several critical junctures where the international community could have better leveraged and empowered the host-nation to improve reform outcomes. 
Security sector reform requires the development of systems that support the rule of law and maintain stability in both the short and long term. In the case of Timor-Leste, some necessary changes were implemented to make this happen, but well-intentioned goals were often perplexed by overwhelming factors. Despite the fact that all of the actors and resources needed to establish a working security sector were present, SSR still failed in its attempt to create a viable rule of law and the institutions to support it. The inability to build this capacity severely debilitated the host-nation from determining its own accomplishments in SSR, and ultimately led the country towards dependency on outside actors, rather than creating sustainable outcomes for future growth and responsibility. In this respect, Timorese motivations for reform were more a function of the international community's incoherence and poor implementation of these initiatives in the early reconstruction period, rather than host nation incapacity.

Despite international stress on host nation capabilities that were fragile or prematurely formed, the hostnation attempted to take responsibility for and enact security rules, institutions, and activities during the Timorization phase of stabilization. The result was two extremes that highlighted the dichotomous results of the reconstruction phase: the Timorese excelled in areas in which they were familiar (mainly community policing and structured reporting relationships) while dramatically failing in others (human rights, chain of command decisions) that were imposed from the outside, or culturally foreign. These divergences are explained by several missteps throughout the reconstruction process: a systemic failure of monitoring and oversight; failure to recognize the appropriate role of 
the host nation in activities; lack of appropriate civil society input in decisions; strategic goals reflected international, rather than local, ideals; and insufficient mentoring to recruit, train, and develop the right people.

A delicate balance must be found in weighing decisions over proper host-nation involvement in SSR with standards expected by the UN and international actors. Careful assessments, intimate communication with and participation of the host-nation, and cohesive goals may all contribute to delegating appropriate activities among actors to ensure successful SSR. Most importantly, actors engaging in security transitions must remember that transition is only successful if the host-nation is mentored and guided appropriately to allow it the opportunity for internal reflection and recalibration of its own goals and programs. 

In August 1999, the people of East Timor voted overwhelmingly against a proposal that would make their island an autonomous province of the Republic of Indonesia. The international community expected that the establishment of a new state would be straightforward. This was because it appeared that all of the factors needed for a successful transition from conflict to peace and stability were present. The reality, however, proved different which is why Timor-Leste serves as a good case study for those interested in postconflict reconstruction and specifically security sector reform. This study builds upon the themes presented in Armstrong and Chura-Beaver's study, Harnessing Postconflict Transitions: A Conceptual Primer (2010), and Practitioner Frameworks on the Host-Nation Role in Transition to Determine how Countries Contribute to their Own Security Transitions (2010).

\section{INTRODUCTION*}

Since the end of the Cold War, the international community has intensified its focus on the role of the security sector ${ }^{1}$ in statebuilding. Security sector reform (SSR) refers to a wide range of security and development assistance programs engendering institutional change within state security organizations so that they are accountable to the citizens they protect and serve. ${ }^{2}$ Simply put, SSR involves the normative and structural transformation (or construction, where absent) of a state's core security actors into effective, professional, and legitimate agents under democratic civilian control. SSR in postconflict ${ }^{3}$ settings faces remarkable challenges as institutions are often afflicted by corruption, politicization, unprofessionalism, and lack of civilian control and accountability that impede long-term development of effective democratic gover-

* The authors would like to sincerely thank INSCT Research Fellow, Shani Ross-Kfir, for her invaluable contributions during the data collection and analysis stages of this monograph. 
nance. ${ }^{4}$ Despite the international community's extensive commitment of financial and human resources to SSR programs, results have been less than modest. ${ }^{5}$

This paper examines the United Nation's (UN) efforts in Timor-Leste (formerly East Timor) as an important case for the study of SSR and postconflict stabilization and reconstruction. We argue that despite presumed favorable conditions especially when contrasted against other contemporary peace support operations, the SSR program has failed. The paper begins with a brief history of the UN's efforts at SSR in Timor-Leste and then presents an analytical framework to assess these efforts based on the Guiding Principles for Stabilization and Reconstruction, co-authored by the U.S. Institute of Peace and U.S. Army Peacekeeping and Stability Operations Institute. Using this framework, the paper highlights several critical junctures where the international community could have better leveraged and empowered the host-nation to improve reform outcomes.

\section{FITS AND STARTS: UN-LED SSR IN TIMOR-LESTE}

In 1999, the UN established the United Nations Mission in East Timor (UNAMET) with the mandate to assist the people of Timor-Leste to hold a referendum as to whether the former Portuguese colony, held under Indonesian rule since 1975, remained a part of the Republic of Indonesia with special autonomy status, or gained sovereign independence. ${ }^{6}$

UNAMET was tasked with registering Timorese voters and supervising the overall referendum process ensuring that it was fairly and justly implemented. On August 30, 1999, the referendum was 
held and an overwhelming number of people voted for independence. Soon after the results were announced, violence broke out in the region creating a major humanitarian crisis necessitating international intervention in the form of the multinational force (INTERFET) under a unified command structure led by Australia. Following a sufficient restoration of peace and stability, the Security Council adopted Security Council Resolution 1272 (October 19, 1999) creating the United Nations Transitional Administration in East Timor (UNTAET). UNTAET's broad mandate included full, albeit transient, responsibility over all law and order, bureaucratic, development, and capacity building efforts that would presumably lead to effective Timorese self-government. Over the next decade, however, multiple UN missions ${ }^{7}$ were unsuccessful in their efforts to develop TimorLeste's security sector.

Figure 1. Timeline of UN Missions in Timor-Leste.

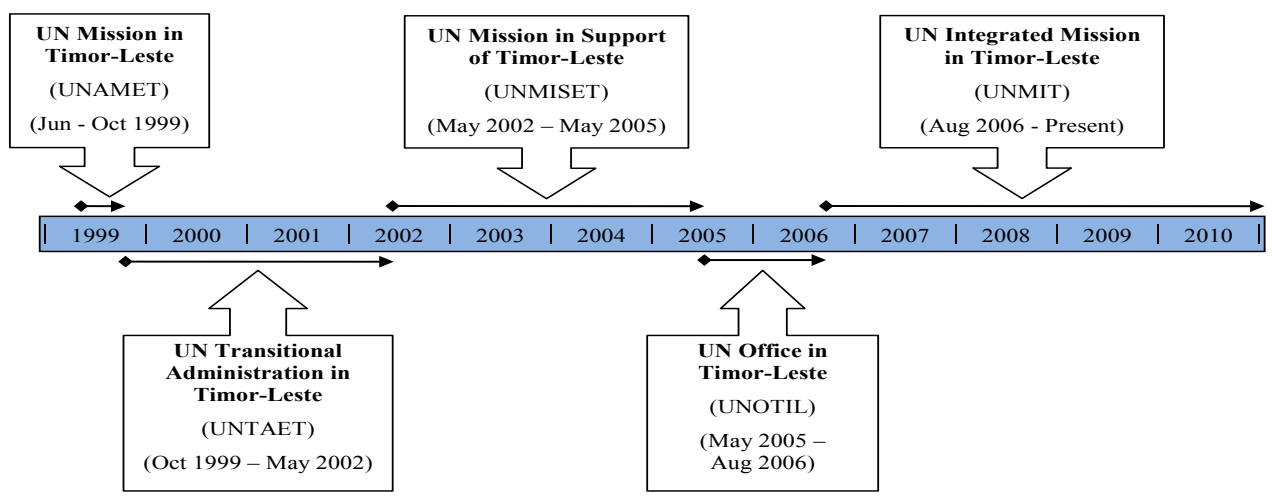


Timor-Leste was initially considered an ideal environment for conducting security sector reform and achieving a peaceful transition to statehood. Indonesian acknowledgement of TimorLeste's independence following the referendum effectively ended the major source of conflict between Indonesian forces and Timorese rebel groups, although some cross-border disputes did occur. ${ }^{8}$ Moreover, there existed a general desire and willingness to engage in institution building within Timorese society. Despite the favorable conditions, the people of Timor-Leste generally lacked the experience and human capital to participate in reconstruction activities. This was due to the fact that much of the preexisting public sector was staffed by Indonesians. Following the referendum, the majority of Indonesian officials fled, creating a vacuum of talent and experience that the international community was left to address. East Timorese lacked the skill and knowledge to assume responsibility for governing Timor-Leste.

Early efforts at SSR were narrowly focused on establishing a basic level of security and developing indigenous police, and later, defense forces. The mandates to conduct SSR were initially separated between UNTAET and INTERFET, where UNTAET focused on governance and oversight matters, while INTERFET attended to providing interim security and creating the Timor-Leste Police Service (PNTL) with the assistance of international civilian police personnel (CIVPOL). ${ }^{9}$ In 2000, UNTAET took control over INTERFET, establishing a unitary organizational structure in advising and training the PNTL. UNTAET therefore formulated a comprehensive police training program that would (1) create the capability for sustainable police services and (2) professionalize the force over the long term. ${ }^{10}$ 
The training was managed by UNTAET for a brief period before control was transferred to Timorese officials. By mid-2003, almost 3,000 officers were"fully trained and able to take on normal policing functions" and the force began assuming authority in communities throughout the country. ${ }^{11}$

Later in 2006, the United Nations Office in TimorLeste (UNOTIL) assumed the police training mission with the purpose of continuing PNTL capacity building initiatives, all similar to those implemented by UNTAET. More progressive programs, including gender training and integration within the police forces, were incorporated into traditional training structures. ${ }^{12}$

UNOTIL was also tasked as a liaison between the PNTL and other government agencies to establish institutions supporting rule of law and governance. Yet, a heightened consciousness of past police discrepancies inhibited the new police force from fully undertaking its responsibilities. Preoccupation with issues of international concern, such as human rights, was deeply embedded throughout the series of UN missions, leading to a systemic neglect of security provision at the local community level. Consequently, the "PNTL were poorly equipped, undertrained and reluctant to investigate cases, yet primary concerns focused on their human rights abuses and abuses of power and an associated developing culture of impunity." 13

Contrasting the challenges of police development, development of a defense force in Timor-Leste was never explicitly mandated to any UN mission. ${ }^{14}$ Rather, the genesis of a self-defense force instead resulted from coalition (mainly Australia, Portugal, and New Zealand) and internal political pressure. Discussion of the establishment of a Timorese military began in 
late 2000, which was highly contentious, especially as many people worried about establishing a military force absent a fully and independently functioning Timorese civilian government, which presented opportunities for military rule. Despite these concerns, international contributors, especially training supervisors, were limited in their options to create a new Timorese defense force.

$\mathrm{UN}$ officials and the participating international militaries (Portugal, Australia and New Zealand) considered available options related to force capabilities. For many, FRETILIN's guerrilla force, Armed Forces for the National Liberation of East Timor (FALINTIL), was a viable precursor to a professional and stable military for two main reasons: first, FALINTIL had experience as a militia in conducting military tactics and techniques, creating a baseline for training; second, the population was already familiar with the force, thus establishing a semblance of legitimacy in providing external security. These reasons contributed to the decision to use FRETILIN as the foundation of a national military force. International trainers believed that the militia could be reformed and integrated with new recruits to make the military more representative of and responsive to the new government. Consequently, in September 2000, the Cabinet established "a light infantry force of 1,500 regular soldiers and 1,500 reservists, drawn initially from the Armed Forces for the National Liberation of East Timor (FALINTIL), the former guerrilla force." ${ }^{15}$ Australia and Portugal, the two biggest training contributors, pledged personnel to oversee this initiative.

Role definition and politicization between the police and defense forces remains a significant prob- 
lem. Between 2000 and 2005, military and police development lagged due to "uncertainty over...roles and responsibilities"16 as the military was frequently re-directed to focus on issues of political and social importance such as dealing with martial arts groups (MAGs), responding to law enforcement issues, and creating specialized forces to combat maritime security issues. The military also undertook investigations in domestic issues when the PNTL was deemed unfit or under-resourced to do so, creating animosity, distrust, and jealousy between the services. This is intensified by politicization within the F-FDTL which resulted from the initial recruitment of former militia members with strong ties to influential political parties. ${ }^{17}$ Societal and political factions were deeply rooted within the defense and police forces and tensions boiled over in 2006, resulting in a renewed international commitment under the UN Integrated Mission in Timor-Leste (UNMIT), and again in 2008 with an attempted Presidential assassination.

It is clear that since the 1999 referendum initiatives to create an effective, democratically governed security sector have faltered. Police and military forces struggle with meeting personnel and resource quotas, recruitment is largely politicized, and the populace perceives security institutions as untrustworthy, ineffective, or both. Large segments of the population remain threatened by martial arts groups (MAGs), guerrilla forces, and gangs and the government often fails to control internal violence. Given these paltry SSR outcomes, how did the international community squander the window of opportunity presented in 1999? The following analysis examines this question in greater detail. 


\section{THE USIP/PKSOI GUIDING PRINCIPLES FOR STABILIZATION AND RECONSTRUCTION}

To frame our analysis, we apply USIP's Guiding Principles for Stabilization and Reconstruction, hereafter Guiding Principles, which provides prescriptive guidance for policymakers and technical advisors implementing security reform programs. It points to a number of best practices that influence security provision such as building host-nation ownership and understanding local context. ${ }^{18} \mathrm{All}$ of these factors emphasize the importance of the host-nation's ability to take control and responsibility for the transition process.

Guiding Principles provides a framework for analyzing the effects-or lack thereof-of host-nation support in SSR. The document offers "strategic principles for all major activities in S\&R [stabilization and reconstruction]"19 according to the five overarching stability goals: safe and secure environments; rule of law; stable governance; sustainable economy; and social well-being. The analysis that follows is tailored to security sector reform, specifically the seven key areas of focus identified in Guiding Principles:

1. Reforms should reflect local security needs. Initiatives and structures created for a viable security environment should meet host-nation expectations and needs. Institutions that support security initiatives should embrace international standards, but not at the expense of cultural norms and traditions. Police forces are considered one of the most crucial pieces in security sector reform, as they interact directly with the population. 
2. Promote good governance and legitimate civilian oversight. Security sector reform should focus on more than just force creation. Management and oversight capabilities should be built to ensure that security forces act appropriately and within host-nation mandates. Governance can also incorporate a vibrant civil society with active participation in oversight and security force reform and procedures.

3. Security forces should undergo a robust vetting process. Security force recruits and appointees should be screened for past violations of human rights and public abuse to help quell public anger that accompanies stabilization operations. Vetting should be uniform and fair which may require the appointment of bipartisan individuals who are able to identify human capital needs and reconcile them with past incursions. Vetting should also ensure that new security forces reflect the composition of the population.

4. Focus on public service ethos and competence during training. Implemented training should focus on developing a culture of international norms and standards as well as capabilities to perform security initiatives. All training should stress accountability in maintaining security, and this can be reinforced through the buy-in and support of local leaders.

5. Improve police-community relations and outreach. Many stabilizing societies have a history of conflict with the police, which needs to be corrected so that security institutions are publi- 
cally legitimate. Police forces should actively engage the public to win this trust and build a community security model. Overall, police responsiveness to public concerns should be the goal when engaging the public.

6. Ensure a coherent strategy and effort among actors. All parties involved in security reform, including international actors, civil society, the media, and the host-nation, must agree on a desired framework to shape security sector reform. All actors collectively should concur on basic security foundations. Security sector reform plans should be collective as well, focusing not only on security forces and laws, but also institutions meant to support basic security tenets.

7. Promote state civil authority. Security sector reform cannot focus solely on the roles of the military and police, but should also concentrate on developing state capabilities to raise, maintain, and deploy forces. This requires a delicate political balance within the host-nation that appreciates national security goals and priorities. ${ }^{20}$

Using the Guiding Principles as an evaluative benchmark against supporting evidence on the mission in Timor-Leste, this monograph investigates how the interactions between international and hostnation actors contributed to failed security sector reform. The authors collected data from a number of sources including UN documents, international and non-governmental organization reports, individual memoirs, media, and a number of secondary sources. These sources were then compiled in a database and 
passages were coded according to the seven SSR principles for subsequent analysis.

\section{CASE ANALYSIS}

When assessing the international community's approach to SSR in Timor-Leste, a few contextual factors should be noted, which inform the proceeding case analysis. One of the most pressing problems in implementing reforms concerned confusion over SSR mandates. UN missions are comprised of an array of personnel from different countries and backgrounds; each tends to have its own interpretation of SSR. ${ }^{21}$ Community policing is an illustrative example of this problem. Each contributing country to the police training mandate had different ideas about this concept and trained their Timorese counterparts accordingly. Thus, the lack of a single definition and consistent understanding of community policing placed the newly trained Timorese at a disadvantage, as police officers approached community policing differently and often deviated from standards set by the new government. ${ }^{22}$

Second, security sector reform initiatives were further complicated by social, cultural, and historical tensions in the country. While these issues were often outside the UN's comprehension, Timor-Leste personnel possessed the deep local knowledge and expertise necessary to address these issues. Yet, opportunities to harness this expertise were often lost since many UN personnel instead favored approaches that satisfied the mandates, goals, and perspectives set by the international community rather than acknowledging Timorese-determined solutions. Most of the SSR initiatives implemented in Timor-Leste lacked the local 
input needed to allow the country to truly "own" its program, diminishing buy-in from local leaders.

Third, long-standing disputes between the various Timorese political groups divided the fledgling nation, with dire consequences for security force recruitment, promotions, and even pay. These were influenced by political or ethnic affiliations, which made integration extremely difficult. The tumultuous political environment following independence also added to the integration problem. Political graft and corruption were-and continue to be-major concerns. Political parties used the security budget as a way to win additional members so as to establish supremacy over the police and military. Timor-Leste also had no experience with democratic forms of civil military relations and policing, where forces are accountable to elected political officials. This wrangling did not foster an appreciation for democratic norms; if anything it caused the opposite.

These issues should be taken into consideration when examining the variables outlined by Guiding Principles since they inform many of the reasons for the failure of security sector reform. Deeper insights into execution flaws are explored in the following sections.

\section{Reforms reflect local security needs}

It was clear that Timor-Leste lacked the physical and bureaucratic infrastructure it needed to effectively govern as early as the summer of 1999, during the weeks leading up to the referendum. Stated earlier, this stemmed from an Indonesian policy mandating that governance matters remained firmly entrenched in non-Timorese hands, essentially denying the Ti- 
morese the initial knowledge, means and capacities for self-governance. To address this shortcoming, it was agreed that for the first three years following the referendum, Timor-Leste was to operate on a quasi-trusteeship system. This meant that the United Nations, operating as a transitional administration through UNTAET, governed the island and led the statebuilding program, which included a Western model of SSR largely indifferent to local cultural norms and institutions. ${ }^{23}$ This Westernized approach to security governance was a poor fit for a fledgling administration struggling with the most basic needs and challenges facing developing nations. ${ }^{24}$

The UN's initial actions were driven by two primary concerns. First, the UN recognized that it needed to provide security for the indigenous Timorese community from a possible Indonesian encroachment or sponsored militia violence, as experienced immediately following the 1999 referendum. The nature and damage of "Operation Clean Sweep" - the name given to violence following the 1999 referendum vote - was so pervasive and debilitating that there were serious concerns for local community survivability. The destruction of property was extensive (as much as 70 to 80 percent of the infrastructure had been destroyed) and over 250,000 Timorese became either internally displaced or refugees. Second, UNTAET had to devise a way to provide security from criminal activity as the rule of law was largely absent in the presence of pervasive poverty. These immediate security concerns led to the privileging of centralized institution building, ensuring that all direction and resources flowed from the capital of Dili. Once the basic political, administrative, and justice systems were fairly well es- 
tablished, the process was intended to integrate and tie-in local communities to the central government. ${ }^{25}$

The UN's misunderstanding of Timorese society and culture was exemplified by UNTAET's approach to institution-building, which failed to consider local structures that survived conflict and the turmoil of a developing state. Following the 1999 referendum the UN's position was "to directly administer, not merely the mission's own organization, but actual territory and its population, as well as to integrate at the local level the multiple dimensions of the operations, in a kind of 'dual mandate."' ${ }^{26}$ In other words, the UN governed the territory as it saw fit, especially since Security Council Resolution 1272 "endowed with overall responsibility for the administration of East Timor and will be empowered to exercise all legislative and executive authority, including the administration of justice." ${ }^{27}$ Problems quickly emerged from a general lack of consultation with local stakeholders, who became resentful towards the United Nations and operations. ${ }^{28}$ Several Timorese leaders claimed that the international community imposed reforms on TimorLeste rather than consulting directly with key stakeholders about security needs, creating unnecessary tension between external and local actors that still exists today..$^{29}$ UNTAET leaders did not engage TimorLeste's top leaders within the national police force and, consequently, the force that emerged lacked strategic vision, coherent identity and institutional loyalty. ${ }^{30}$ Moreover, efforts to assess and respond to security needs were affected by conflicting perspectives and perceptions of the internal security threat between Timorese officials, donor groups, and UNTAET. ${ }^{31}$ No two groups espoused similar views, and host-nation exclusion from negotiations was detrimental to the 
planning and execution of security sector reform programming. In sum, host-nation leaders, especially at the local level, were necessary to legitimize reforms yet they were largely excluded or forgotten in the process. Meanwhile, the UN was the sole actor determining who was involved in designing and implementing SSR initiatives and also enacted their own monitoring system in the process.

UNAMET and UNPOL initially maintained strict control over most activities, allowing Timor-Leste to function independently only at the local level (i.e., some police training and foot patrols). Local structures were only utilized or consulted in the event that the new police force was unable or unwilling to handle incidents that arose. ${ }^{32}$ In most cases, cultural and historical norms were ignored as part of the solution to solve security issues. Local Timorese leaders complained about UNTAET's, and later UNMIT's, inability to listen to the needs of those most affected by on-going insecurity and their unwillingness to use local support, despite public opinion which favored traditional security structures. Over 81 percent of the Timorese population polled in 2004 acknowledged that they viewed their local leaders, rather than government-run police, as responsible for maintaining internal security. ${ }^{33}$ Interestingly, UNTAET's initiatives to build a central police force were blatantly at odds with popular sentiments; rather than build on pre-existing norms and institutions for gradual transformation, UNTAET implemented completely new methods to establish and maintain security norms. Worse yet, both UNTAET and UNMISET failed to forge a working relationship with senior community leaders to work towards common security goals. 
Part of the difficulty in building or integrating complimentary security structures was the UN's inability to communicate with its counterparts in country. Despite the UN's best efforts, language skills were difficult to impart on frequently rotating peacekeeping forces and the short deployments left little time for peacekeepers to become familiar with cultural nuances and partners. This did not improve even with the UN's prolonged presence; in fact, most laws, policies, and inter-institutional documentation were written in English and Portuguese rather than Tetum, making it inaccessible to the majority of the population. This not only isolated the population from the development of the security sector, but also inhibited the UN from consulting local stakeholders who could more appropriately frame initiatives. ${ }^{34}$ Many community leaders, especially at the local level, cited concern that the UN and central government were willing to incorporate rural input. All attempts by the UN to work with local leadership on these issues (especially Xanana Gusmao and Jose Ramos Horta) were not publicized, giving the impression that the local community was ignored all together in the SSR process. ${ }^{35}$

UN efforts to institutionalize democratic norms in security sector practices were piecemeal at best. Democratic governance is essential to ensure free, fair, and equitable adherence to the rule of law in any country and it is a key component of any SSR process. Yet, the UN failed to promote the institutional character needed to uphold a purely democratic state. Analysis of efforts to "democratize" the security forces uncovered numerous failures: trainers implemented their own standards of democratic law enforcement in training (some of which were in violation of international standards), host-nation police forces mimicked Indo- 
The 2000 King's College report analyzing Timor-Leste's security sector called for a different approach to the security challenge. The report suggests that the country required both a military and police force to deal with emerging security threats. The report bases this finding on the emergence of issues related to outside influence and border disputes, most especially maritime security issues. The PNTL, focused on internal security, was not equipped to handle these types of problems. Initially both the UN and the newly formed Timorese government were hesitant about creating an East Timorese military, especially since the recruits for such a force would come from former guerrilla groups. These groups were considered dangerous to democratic processes and oversight, since they traditionally acted without government mandate or leadership. Despite these reservations, an external defense function was created separately from the PNTL to focus exclusively on border issues including maritime security. The bulk of this new force would rely on the experience and leadership of Timorese who had previously participated in militia or guerrilla activities. While vetting was implemented as part of recruitment, ensuring adequate capacity for such a force forced the government to integrate former guerrillas into the new, highly structured, Western-model force. nesian police practices that often disregarded international standards, and new security organizations failed to reach out to the local population. ${ }^{36}$ This ad hoc approach further dissuaded the many actors involved in Timor-Leste reconstruction from consolidating a common plan for reform. Thus, the basis for encouraging participation in the security sector, a key component of democratic governance, was undermined by the lack of cohesion between the UN, local institutions and civil society actors to promote democratic law enforcement.

A final issue concerned the decision to have two distinct organizational entities (UNTAET and INTERFET) to oversee security force development. SSR planning documents placed little to no emphasis on maintaining coherence in building forces that would counteract pressing security threats. Additionally, little attention was given to designing security forces based on a proper assessment of potential internal and external security threats. Initially security sector reform 
Security force integration was difficult, but not as arduous as ensuring that security forces were immune from political manipulation. Since the creation of both the PNTL and F-FDTL was overseen by different groups (the PNTL by CIVPOL and the F-FDTL by a coalition of countries and the new government), the host-nation government privileged the defense forces over the police. In most instances, the PNTL was ignored or neglected in receiving necessary personnel and resources to make it a functioning entity, while the military was catered to by ex-military officials with government positions. The F-FDTL received preferential treatment because it was considered a more organic organization for security; the PNTL was recognized as a UN project with little host-nation input. The competition between the two forces was so pronounced that it elicited local community attention, which noted responsibility overlap (especially police work) and lack of cooperation between the organizations. Such a situation only further soured the host-nation's outlook on developing a security structure predicated on Westernized norms and structures. meant building a Timorese police force, yet this evolved as local political debates and international concerns over the need for multiple security structures within the country trumped this goal. Most of all, it contributed to an already standing tension between the Timorese guerrilla groups who fought for independence and the new security forces in development.

Overall, UNTAET failed to respond to local security needs by implementing its own response without the help of the host-nation. The failure to determine security needs through the assistance of trusted local leaders and new government officials resulted in a chasm between international efforts for reform and national needs to establish a safe and secure environment for citizens. Moreover, indecision over institutional design, functional establishment, and separation of police and military roles created additional stress in reconstituting an apolitical security sector with adequate civilian control mechanisms. Conse- 
quently, many of the activities undertaken during SSR remained largely at odds with reality in Timor-Leste.

\section{Promote good governance and legitimate civilian oversight}

The UN acknowledged the need to establish systems that would develop the PNTL and F-FDTL into fully-functioning, legitimate, and democratically governed organizations. To do this, both good governance in the form of standard government practices and legitimate civilian oversight, including systems and methods used to verify and check activities, were stressed. Yet, these good intentions were sidetracked as efforts to build capacity quickly took priority. Timor-Leste offered a unique challenge in that during the initial stage of reconstruction there was no external threat, especially once Indonesia left and militias had been neutralized. This may explain why the donor countries and the UN felt that they should focus on governance and institution-building rather than security. Initial assessments of Timorese capacity noted significant gaps in systems and processes, ranging from little to no management expertise available in the country, to deficient or non-existent systems needed to oversee activities, to leadership lacking proper authorities to create new institutions. ${ }^{37}$ These factors stood as barriers that would delay the quick equipping of security forces since no mechanisms were in place to achieve these goals.

Political and military rivalries shaped TimorLeste's dynamic security problems. Tension between politicians and military officials undermined UN efforts to establish civilian oversight mechanisms that were adhered to by security personnel. The first 
in solving this problem was to address the issue of personal relationships between political parties and freedom movement groups, most notably military factions. Many independence-affiliated parties emerged as armed militias or factions during the preindependence period and achieved reputations for acting violently to achieve political purposes. Both the East Timor National Liberation Front (FRETILIN) and National Council of Timorese Resistance (CNRT), two of the most popular groups, were categorized as such. It was widely believed that FRETILIN would lead the country in the aftermath of independence because of its eager following by many citizens and active support in driving the independence referendum. ${ }^{38}$ This proved woefully incorrect, especially as the international community became engaged in the conflict. Instead, the international community tried to deflect the group in favor of the more centrist Popular Council for the Defense of the Democratic Republic of East Timor (CPD-RDTL). The problem was that FRETILIN maintained control of the most proficient militia in the country, a force capable of overwhelming or aggravating the new government established in Timor-Leste. The fear was that FRETILIN would use this force to regain political prominence, either by hijacking new security institutions through saturating the organization with recruits or overtaking political power through force.

Despite calls to establish new, democratic security systems accountable to civilian institutions, UNTAET decided to develop security mechanisms prior to the foundation of oversight protocol. The goal was to implement oversight mechanisms after the full establishment of security institutions to ensure that police and armed forces could perform their jobs and have 
some experience before being evaluated. This was thought to increase the successes of the police and military by focusing exclusively on tactical training rather than political concerns. Yet, the result of this decision was devastating. While the UN missions focused on training PNTL and sped up the transition of policing responsibilities, disdain for civilian oversight grew. Political parties gained power and attempted to manipulate resources for their own profit and influence. Security forces, especially the military, were not exempt from this. ${ }^{39}$ Many analyses of the political process during this time note that politicians stood to gain from "overseeing" security forces; the PNTL and F-FDTL were easily manipulated to serve individual politician preferences by leveraging access to resources and career progression. ${ }^{40}$ The problem of corruption, a form of security force misuse, was not addressed until 2009 when the Timorese government established the Office of Inspection to oversee police forces. While the establishment of this institution was a milestone in creating oversight mechanisms, it was riddled with problems including poor training, lack of resources and authority, and a reputation among the police as aggrandizing minor complaints. ${ }^{41}$ The ineffectiveness of this organization was further revealed when, in late 2009, polls showed security service disdain for civilian oversight, noting that they ignored legislation, failed to respond to inquiries, and did not abide by new regulations. ${ }^{42}$

The absence of civilian oversight had an effect on civil society participation in security development. Civil society played little role in planning and implementing mechanisms to make the PNTL and F-FDTL effective. In fact, most civil society organizations worked independently from government-backed ini- 
tiatives due to a lack of communication. This discontinuity between civil society and the UN resulted from several sources: first, the UN did not appreciate the role of these groups in reaching out to rural populations early in the SSR process; and second, many civil society groups were ostracized because of the language barrier - the majority of UN and central government figures did not speak Tetum. ${ }^{43}$ This inability to harness civil society influence resulted in popular distrust as well as wide-spread misunderstanding of how the populace traditionally helped oversee police activities. ${ }^{44}$ The public remained skeptical of security forces because their trust was not won during the early stages of security sector development.

Some of the skepticism attributed to poor policepublic relations was diminished with the establishment of civil society forums in 2003 . UNMISET used these forums as an avenue to establish public oversight of police activities, promote transparency in security structures, and encourage public participation in security planning and development. ${ }^{45}$ These forums bolstered efforts to establish ties between the police and local populations, a necessary step in establishing legitimacy for new security institutions.

Training initiatives also attempted to build a police force with direct community ties. International donor initiatives were specifically active in integrating community policing standards into police activities. Initiatives by donor countries, including the Japan International Cooperation Agency (JICA), helped train security forces on how to interact with the population through community policing activities. The Koban Community Policing Program ensured that police efforts linked directly with local development goals and strategies, creating a more unified SSR vision. ${ }^{46}$ While 
these projects were helpful in developing some community building skill sets, they often were disjointed by UN development plans meant to build the PNTL. Many programs were initiated separately from regular police training, disjointing sector initiatives, and were not consistent among forces.

Overall, despite failures during initial attempts to promote good governance and civilian oversight, the UN discovered and pursued mechanisms to achieve these goals. Yet, these oversight mechanisms can only be characterized as ad hoc at best. The incorporation of civil society into oversight mechanisms of security services and policymakers created a more transparent process to recalibrate activities.

\section{Robust vetting of security forces}

Crucial to the establishment of a legitimate security force is ensuring that the people recruited to fill these positions respect the rule of law and are willing and capable of enforcing it. International observers and trainers in Timor-Leste acknowledged this and incorporated several vetting techniques into the recruitment and training of police and defense forces. Many of the programs successfully removed individuals that were ill-suited for such positions. However, domestic political and international pressure undermined the vetting process, which meant that unqualified individuals were allowed to join security forces.

UN efforts to establish criteria for identifying corrupt or incapable individuals for the police and defense forces were feeble at the outset. In fact, the various foreign trainers were unsure how to identify who would pose problems for the new forces because they were unacquainted with the political and social 
distress that permeated the country. This intelligence gap compelled the UN missions to rely on the advice and support of Timorese institutions in creating selection and vetting procedures that would assist PNTL and F-FDTL recruitment. Although this method of vetting may be ideal in handing ownership to the hostnation, the results proved to the contrary, especially in respect to the F-FDTL, as it politicized the selection process. This was because F-FDTL selection was based on political loyalty to Prime Minister Gusmao and Brigadier General Taur Matan Ruak, ${ }^{47}$ as opposed to being driven by individual merit and skills. Such recruitment practices allowed corruption to permeate the organization early on, and caused concern about the viability of the institution. Other issues, including the lingering effects of Indonesian occupation, also affected the vetting and selection process. The PNTL was especially impinged by this, since many recruits were dropped merely for prior affiliation with the Indonesian police forces. ${ }^{48}$ The lack of experienced recruits who could pass police vetting standards stymied the institution, especially since most personnel hired for the force lacked basic skills to enforce the new rule of law.

Indeed, these issues uncovered a series of dilemmas for the international community and Timor-Leste as its security organizations grew in size. Vetting officials had to balance the risk of eliminating vital human capital with retaining key individuals whose past may have conflicted with vetting standards. The PNTL suffered with this problem because of its criticality to the new nation and SSR while also maintaining a less than stellar history in East Timor. The PNTL was viewed as illegitimate by the population from its inception, especially when it was revealed that 350 
Timorese affiliated with the Indonesian government were appointed to mid-level management positions. ${ }^{49}$ Although these individuals were qualified for their positions, their hiring caused much consternation with the public who blamed them for wrongdoing during Indonesian occupation. The UN attempted to combat public perception of corruption by engaging in a one-on-one mentoring program which matched international police trainers with Timorese officials. Unfortunately, no publicity was undertaken to change public opinion about how and why certain officials were chosen to lead the PNTL. The public was also not informed about how personnel and systems were reformed and evaluated using the new SSR process.

The UN missions also had to grapple with recruiting socially, politically, and ethnically diverse police and military forces. Unfortunately, the post-independence situation was such that it became extremely difficult to recruit individuals rather than groups to take on security responsibilities. Recruits with the most experience usually came from sectors of society affiliated with freedom fighters and militias. As such, the recruitment and selection process, focused on maximizing policing and military skills, used a disproportionate number of former military personnel to fill police and military slots, overlooking individuals who needed training in favor of pre-trained and experienced individuals.

In the absence of a functioning security sector and with persistent internal and external threats, the Timor-Leste government was anxious to fill police and military institutions to provide security to the populace. A first response to this need was to recruit former police officers to take on the job; this is exactly what the host-nation did to respond to UN requests 
to create a police force. ${ }^{50}$ While this was not ideal for diversifying the force, the group recruitment method did create a baseline force that could be expanded appropriately to conform to government mandates and security concerns. Unemployed youth were also a quick solution to meet recruitment quotas as well as former freedom fighters from POLRI and Falintil; over 100 members of these groups were incorporated into the PNTL in a political effort to neutralize them. ${ }^{51}$ All methods to grow the security force demonstrate that no common plan existed to identify and hire qualified individuals. ${ }^{52}$ To adequately recruit individuals for the right jobs, the UN needed to impose uniform standards to recruit, train, and retain individuals.

The push to recruit groups into the security forces resulted from the need to represent diverse sectors of the population. Diversity in force structure demonstrates incorporation and unification in postconflict states and gives the population a stake in ensuring stability. In the case of Timor-Leste, allowing ethnic, gender, and religious affiliations proportionate to the population was a critical step in gaining traction with the rural population. The UN encouraged recruitment from representative groups shortly after other recruitment methods were implemented by the host-nation. In this instance, the UN instigated representation among the police and defense forces by setting their own quotas for proportionality. This, too, revealed problems, as international actors slowly understood that unique local methods of policing struggled to match or meet international standards. The inclusion of local groups not only distorted the uniformity introduced in UN training for police, but also bred rivalries. The F-FDTL suffered from this the most, as many senior leaders focused on members' 
cultural ties rather than skill and training. This was because a number of F-FDTL senior leaders used their own cultural heritage (mainly village affiliations) as a guideline to promote soldiers, fueling resentment within the ranks. This eventually caused soldiers to protest in January 2006, which later, in April, escalated into violent clashes between the military and police forces. ${ }^{53}$ Hence, oversight for incorporating diverse ethnic, religious, and regional groups was remiss in undermining consternation among recruits, leading to a breakdown in organizational structure and management.

All of the problems outlined have focused on recruitment and standards, but oversight and evaluation also factor into robust vetting. This function was largely ignored in the initial stages of SSR, but became a concern when dysfunctions were discovered in security force training and implementation. Preliminary standards for monitoring and evaluation determined that over half of police units were incapable of undertaking traditional police responsibilities. ${ }^{54}$ Yet, without a formalized, legitimized function to reveal this discrepancy, the PNTL was permitted to take on responsibilities without evaluation of their readiness. The UN mission failed to establish an evaluation and monitoring wing to oversee police development; the host-nation did not have the expertise or willpower to establish one on its own. In fact, the UN did not establish an evaluation branch in Timor-Leste until 2010, when uprisings between the PNTL and F-FDTL prompted the organization to investigate the cause of such rivalry ${ }^{55}$ Lack of oversight and thorough monitoring not only prohibited the PNTL and F-FDTL from learning from mistakes and redirecting their course, but also made the UN liable in undermining very fragile Timorese structures. 
By reviewing the recruitment and vetting process in Timor-Leste, it becomes clear why the security sector has deep flaws. The failure to develop a strategic outlook and stable procedures meant that recruits were drawn from a variety of sources without an understanding of how they would function in the system and with one another. In other words, not much thought was given to whether individuals from different backgrounds and affiliation would and could serve together. This greatly affected Timor-Leste's ability to develop the skills needed to establish a transparent system for staffing. A corrupt and politicized system of recruitment emerged in the absence of strong and directive leadership.

\section{Focus training on public service ethos and competence}

Security force training was essential because it was supposed to help create a security sector that would meet the needs of the new Timorese state. An important element of the training was to help the new recruits develop and adopt a public service ethos that focuses on community building and professionalization. Community outreach, training scenarios, and relationship building with leaders were all methods adopted as the PNTL and F-FDTL developed. The UN and international actors recognized the need for these programs, especially with growing consternation among the populace about internal security problems.

In Timor-Leste the new forces not only exhibited their mastery of basic policing and military functions, but also had to demonstrate an ability to excel in specific areas of expertise supporting police activities. In the case of the PNTL, the UN slowly introduced 
technical training and education as the organization expanded and stabilized. Some of these programs included study of investigations, legal proceedings, administration, and border security. ${ }^{56}$ Many of these more technical approaches were driven by international contributors to police training, mostly based on trainer expertise and professional drive. Despite calls for such programs, gaps in creating and maintaining such programs appeared as the PNTL grew. Not only was the PNTL short on resources to provide this training, but the majority of recruits lacked skills in basic training critical to building expertise in more detailed and defined policing activities. One NGO source noted that the PNTL could not take the necessary step to professionalize the force because they lacked the resources, personnel, and support to do so. ${ }^{57}$ In addition to this, most programs were entirely dependent on international trainers to create niche programs and positions. Little emphasis was placed on building host-nation police force capacity to teach and undertake these activities (especially planning, forensics, and management) for long term Timorese development. Inappropriate training techniques and equipment only compounded this problem; for example, the use of computer programs for filing and police reports was unsuccessful in rural areas since the trainees had never used a computer prior to serving in the force. The program was too advanced for their skill sets, much less to be used in their day-to-day job

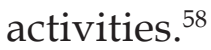

PNTL and F-FDTL suffered from both a lack of political affiliations and poor personal relationships with senior civilian leaders in the government, contributing to the inability to procure support and resources needed for enhanced force competence and reliability 
as part of security sector reform. The PNTL was particularly notorious for working within its own institutional boundaries rather than reaching out to national leadership for support. In fact, the PNTL refused to respond to Timor-Leste leadership during its initial founding, ostracizing itself from officials with influence in resource allocation. ${ }^{59}$ Some argue that this disunity resulted from UN influence since CIVPOL failed to allow senior Timorese leadership a role in PNTL development from the very beginning of its creation. ${ }^{60}$ Further, the few UNPOL advisers that served as liaisons between the PNTL and Timorese government were ineffective at establishing open relationships between the two. ${ }^{61}$ Some initiatives have been undertaken to reestablish police force and government official relationships, but success is still undetermined. The Timor-Leste Police Development Programme (TLPDP) attempts to connect police officials with legislators and will hopefully show promising results over the next couple of years. ${ }^{62}$

In line with political affiliations, the security forces also strove to increase community satisfaction in order to legitimize their existence. Again, the PNTL has been much better at increasing its public presence in comparison to its military counterpart, but this resulted from differences in the focus of work. ${ }^{63}$ Community outreach intended to build confidence in the new institution, especially after years of turmoil and abuse undertaken at the hands of Indonesian authorities. Increased presence in rural communities and engaging in dialogue with Timorese citizens were considered crucial steps in earning public support and recognition. Despite initial pressure from the UN to engage in community oriented policing methods, the PNTL struggled to augment its presence in the population. 
Part of the issue stems from the inability (or perhaps lack of oversight) of the PNTL and the UN in gauging the population's expectations and needs for protection provision. ${ }^{64}$ Efforts to ameliorate this distrust have been hampered by resource, training, and personnel constraints; the PNTL does not have enough trained recruits to undertake foot patrols to show a force presence (this responsibility usually falls on international observers) and attempts to place community members in staff positions at the training academy have been rejected by some leadership. Overall, community outreach continues to be lackluster in fostering public support, and the public continues to question the role of security institutions in the country.

\section{Improve police-community relations and outreach}

The PNTL's role in community relations was critically important in the SSR process. The organization's dependency on the public as both a place of work and as a client made it especially important to establish good relations with the community. Prior to Timorese independence, Indonesian police forces viewed the public as an obstacle to policing rather than a tool or partner. This attitude amplified the sense of public uncertainty when the UNAMET mission emphasized police force creation in the newly independent state. Past perceptions about the security force's view of public interaction effectively poisoned community trust in new security institutions.

Despite acknowledging the need to establish relationships with rural communities, community outreach in project planning was poor. The public and local communities were not consulted on security needs during initial security assessments; this 
resulted from a lack of initiative on the part of TimorLeste's political leadership, UNTAET, UMISET, UNPOL, and organized civil society actors to engage in discussion. ${ }^{65}$ Further, institutions created to provide internal security were constructed in such a way as to limit community access for public involvement. Some analysts argue that this resulted from UN blueprints for an "ideal" force ${ }^{66}$ aimed at establishing a security sector based on international standards without much consideration of local needs and concerns, forging a wider gap between police and the communities they served. ${ }^{67}$ Others contend that as the PNTL formed, the organization became more militaristic in its functions and outlook, separating responsibilities from traditional community policing norms. Both explanations explain why the police are not more sensitive to public involvement, especially when the PNTL would not entertain public forums, de-emphasized community relations in training, and did not consult with local officials on security concerns. "By and large, civil society and the general public have had limited involvement in SSR in Timor-Leste. Reform initiatives until recently have been driven by the UN or international donors, based on input from political elites and senior commanders, but with insufficient mechanisms created for public involvement. This has resulted in reform programmes with minimal community ownership and questionable impact." 68

The PNTL cannot bear all responsibility for failing to improve community outreach, as some of the blame must be attributed to the public and NGOs, which were also unable to forge a working relationship between police forces and the populace. From the outset, the public was skeptical about the new police force and this skepticism affected initial conversations between 
the groups. Even though civil society was shut out from initial meetings regarding structure, there still were opportunities to express opinions about police sustainability and reform. The NGO Forum, a network created by international aid workers, helped civil society express its voice by connecting PNTL leadership with community groups; this was a much needed step in reestablishing relations. ${ }^{69}$ The Forum also noted that civil society needed as much training on communication skills as the PNTL, acknowledging civil society's role in better community-police relations. UNTAET also endeavored to improve public participation in police building through educational programs on SSR topics. The program successfully trained over 100,000 Timorese on communication skills related to security issues, which fostered relationships with the PNTL. However, this program was conducted primarily in English, isolating many sectors of the rural population which spoke Tetum. Despite this fact, civil society did engage in activities that advanced their stance vis-àvis the PNTL to form a working security relationship.

Community outreach and affiliation peaked in early 2000 when UNTAET announced plans to enact "Timorization" of government and security institutions. The Timorization process handed leadership responsibilities to the Timorese as part of the transition from UN to host-nation responsibility. Part of the Timorization process included public access to government organizations; this included engaging in more lively discussion about changes needed throughout the country. ${ }^{70}$ As leadership positions were filled by Timorese, rather than UN mentors, community forums and open meetings with the public increased. This greatly impacted public perception of security forces as the PNTL demonstrated a desire to work alongside 
the populace to achieve mutual security goals. The Timorization process emphasized community roles in ensuring security by using the populace as a vehicle to achieve broader goals. This step significantly contributed to creating the conditions necessary for full participation of the host-nation in SSR.

\section{Ensure a coherent strategy and effort among actors}

Coherent strategies are critical to develop plans that address security problems and needs. Planning falls largely on actors' cooperation and communication about stability activities and projects. TimorLeste exemplified these issues in its own SSR strategic plan as disunity between the UN, host-nation groups, and international donors appeared. UNTAET's mandate undermined its ability to exert leadership capabilities in country. Once Timor-Leste was established as an independent state, national institutions were endowed responsibility for numerous activities. While this leadership was helpful in developing SSR plans, it deemphasized the need to place the host-nation in charge of activities that would develop and sustain SSR initiatives. Consequently, discrepancies between Timor-Leste and UN personnel over SSR responsibilities and activities created a leadership void; without defined leadership for all SSR activities, no clear guidance was established on how to accomplish or analyze SSR success. ${ }^{71}$ Instead, the UN and Timor-Leste worked independently on their own SSR initiatives, often diverging on what needed to be accomplished.

More clear guidance on security sector project plans was not unveiled until 2001 by CIVPOL. CIVPOL overtook the project lead once the Timorese government asked for assistance in developing strate- 
gic goals. The lack of host-nation participation after CIVPOL's takeover, however, created more obstacles in developing a truly strategic plan for whole of security sector reform. ${ }^{72}$ CIVPOL's 2001 plan, while creating a path for stability, focused too exclusively on particular institutions and tactical operations (mainly police training and development) while failing to couple this with a broader community development strategy. ${ }^{73}$ Overemphasis on specific training initiatives ostracized many Timorese trainers; the majority of the established police force was not consulted or used as advisors in developing tactical training programs highlighted in the plan. ${ }^{74}$ In addition, a lack of coherence and clarity in definitions (especially "community policing") and training procedures further muddied efforts to widely develop the SSR strategy. Individual actors tended to operate according to their own country standards, following individual plans apropos to their own countries rather than those outlined by CIVPOL or the Timorese. ${ }^{75}$

The 2001 CIVPOL plan neglected Timor-Leste's role in planning, guiding, and implementing SSR activities. In fact, many Timorese argued that traditional and local security provision standards were ignored in all planning and implementation. This lack of input displaced Timor-Leste's most vital social unit-the community - from actively participating in security transformation using organic methods of training and development. CIVPOL decided against using local institutions because many of its traditional SSR guidelines did not approve of local methods to handle crime and rule of law issues. ${ }^{76}$ Instead of consulting with the host-nation to amend traditional means with international standards, UNTAET ignored the methods altogether. The result was that communities, especially in 
rural areas, refused to recognize the PNTL or other security organizations, regardless of whether they were backed by the central government. ${ }^{77}$ The host-nation was needed to develop security structure plans, and should have been included in implementing reforms to address security issues with cultural and local finesse.

The opposition between the host-nation, civil society organizations, UN missions, and international donors in conducting SSR planning contributed to some failures, but the inability to streamline activities was even more devastating. Activities performed across the sectors (police, judicial, military, administration, etc.) were not integrated into a common plan because actors were unwilling to cooperate. The lack of coordination and cooperation failed to integrate activities for the common goal of strengthening security. One source noted that

There has been no shortage of SSR programmes in Timor-Leste. Since the departure of Indonesian security forces and Timor-Leste's independence, the need has been not merely to reform, but actually to form an official state-run security sector. Until recently, this task has been largely driven by international actors who, despite their best intentions, have lacked the coordination needed to help build a cohesive and unified security sector. ${ }^{78}$

The lack of an institutional framework contributed to actors' inability to coalesce activities for a common purpose. There was no clear chain of command or authority to begin dialogue for activity coordination across all sectors, or with all actors. ${ }^{79}$ Political impetus in this process further complicated efforts to agree on activity guidelines; security stagnation resulted from political quagmire. 
In 2003, the Joint Assessment Mission (JAM) conducted by the Timorese government, $\mathrm{UN}$, and partner countries concluded that institutional strengthening would bolster the PNTL and supporting institutions, as well as establish a defined chain of command structure between them. The report cited the lack of strong leadership as an impediment to forge cooperation between security organizations in the country. ${ }^{80}$ The inability for all organizations in the security sector to work together undermined the rule of law; for example, police could capture criminals, but without a strong judicial sector operating in conjunction with policing activities there were few prosecutions upholding new criminal codes. ${ }^{81}$ Political quarrels about how to increase this interaction under host-nation leadership initially stalled attempts to respond to the JAM's assessment. Some progress has recently been made to establish a leadership group consisting of key government and local leaders for streamlining SSR activities. ${ }^{82}$ However, continuing disunity proves the government's - and hence the UN's -ineffectiveness at creating a system of security organizations that can respond to pressing community needs. The Timorese government continues to view national and local concerns as separate entities with no impact on each other..$^{83}$

Initial security sector assessments prove that opportunities meant to secure SSR success were ignored. Soured relationships between actors catalyzed new gaps in the security sector rather than developing an environment that fostered interaction and partnership. Poor leadership, lack of frameworks, and frenetic planning are culpable in Timor-Leste's inability to develop a reconstruction plan, replacing it instead with actors contributing to insecurity. 


\section{Promote civil authority of the state}

The promotion of the rule of law in recovering states requires the state to govern effectively. Most postconflict states deal with the fact that military methods to ensure peace and stability in the shortterm are normal; the most daunting work is to shift this focus to broader ways of implementing the rule of law. Civil authority is critical as it ensures security forces are operating under the authority of civilian infrastructure and are accountable to local officials and the population.

International actors must highlight the role of local leadership to build its legitimacy with both the populace and security institutions that support it. In Timor-Leste the UN missions often overrode Timorese government authority to pursue its own SSR initiatives. It was difficult for the UN to let the host-nation lead, especially in circumstances where the government lacked capacity to oversee SSR. ${ }^{84}$ While the organization, especially through UNTAET, stressed the importance of maintaining local ownership in most SSR activities (through Timorese government-led initiatives), the actions of the UN missions did the opposite. PNTL training and implementation is one of these instances where UN authority superseded that of the Timorese government. This undermined many opportunities for security sector institutions to be truly organic, local, representative, and responsive to the central government system. Monitoring and evaluation caused concern in maintaining a host-nation lead in activities. The minimal evaluation that took place was conducted exclusively by UN organizations and did not mentor or consult the Timorese government throughout the evaluation process ${ }^{85}$ Not only did 
this fail to impart important skills to the government to evaluate its own progress in the future, but it also blinded leaders to many emerging problems in the security sector. Exclusion in key decision making, planning, and training activities rendered host-nation civil authority inept at conducting activities to positively affect the security sector. In effect, the UN operated almost like a shadow government ${ }^{86}$ in the country; it competed with the Timorese government to gain legitimacy rather than bolster host-nation initiatives. ${ }^{87}$ The UN's actions as a monitor had the unintended effect of stifling Timorese institutional growth.

Building civil authority requires a trial period where mentors can guide the host-nation in how to appropriately handle responsibility. It may be said that the UN, while not giving the lead to the host-nation, did attempt to mentor their counterparts following the establishment of a viable political system. The UN acknowledged later that it had to learn how to mentor rather than dictate changes in order for the government, and security sector as a whole, to be sustainable after withdrawal. ${ }^{88}$ Such a mentoring program focused on building individual relationships with the Timorese in order for the UN to follow a timeline to handover responsibility. Many security sector organizations received individual personnel to work one-onone in learning functions and roles in the new security system. Mentors focused on building leadership capacity, teaching their counterparts how to use tools to effectively perform their jobs, work on negotiation/ interaction skills with leadership and government officials, and follow international guidelines such as those laid out for human rights. The success of this program relied on the mentors and mentees themselves; partners with good relationships and training 
often succeeded, while those with less amiable relationships tended to falter in their positions. The biggest criticism of the program focused on building a dependency on international mentors. Some of the systems put in place by the UN surpassed host-nation understanding and required on-going $\mathrm{UN}$ presence to sustain them. Computer programs initiated to maintain files were one example; many host-nation counterparts did not understand how to use computers, much less the filing program, and could not learn it before their mentor left. ${ }^{89}$ Needless to say, the mentoring program did promote civil authority by beginning to impart the skills needed to establish working relationships between the government and security sector counterparts.

Timelines were also created as a way to strengthen civil authority and drive progress over the course of the UN missions. Yet, some goals were based more on the politics of long-term international commitment than on realistic assessments and expectations of postconflict reconstruction. Many of the UN missions were mandated for short periods of time and were tasked with problems that required a great deal of work, rigor, and attention to time spans. As such, timelines ensured that certain activities and projects were completed in order to comply with the strategic goals outlined by the UN. While timelines were helpful in pushing the host-nation to assert its authority in many activities undertaken by the UN early in the reform process, they also posed some issues in respect to strengthening the government as a whole. Some Timorese believed that the timelines were too fast or rushed, leaving them inadequately prepared to take full responsibility of security activities. ${ }^{90}$ Others contended that organizational timelines were not synced 
correctly and left the security system as a whole much weaker; some organizations were fully capable of their responsibilities while others struggled to perform their own, much less support partner organizations. This created a skills gap between organizations as some succeeded while others struggled to complete day-to-day activities. The Timorization process undertaken by UNAMET accelerated the handover process by placing more host-nation leadership in charge of SSR activities with the UN serving an oversight role. Some suggest that Timorization pushed the hostnation leadership to finally take responsibility of their actions, while others argue the UN turned too many responsibilities over too soon. ${ }^{91}$ Overall, the UN accomplished a great deal in developing civil authority through the use of timelines, serving as benchmarks for the establishment of credible host-nation leadership. However, this also highlights an important and often politically difficult lesson that proper sequencing requires decision making based on local realities, not necessarily by international political demands for a 'quick fix.'

\section{CONCLUSION}

Security sector reform requires the development of systems that support the rule of law and maintain stability in both the short and long term. In the case of Timor-Leste, some necessary changes were implemented to make this happen, but well-intentioned goals were often perplexed by overwhelming factors. All of the actors and resources needed to establish a working security sector were present, but SSR still failed in its attempt to create a viable rule of law and the institutions to support it. The inability to build 
this capacity severely debilitated the host-nation from determining its own accomplishments in SSR, and ultimately led the country towards dependency on outside actors, rather than creating sustainable outcomes for future growth and responsibility. In this respect, Timorese motivations for reform were more a function of the international community's incoherence and poor implementation of these initiatives in the early reconstruction period, rather than host nation incapacity.

Despite international stress on host nation capabilities that were fragile or prematurely formed, the hostnation attempted to take responsibility for and enact security rules, institutions, and activities during the Timorization phase of stabilization. The result was two extremes that highlighted the dichotomous results of the reconstruction phase: the Timorese excelled in areas in which they were familiar (mainly community policing and structured reporting relationships) while dramatically failing in others (human rights, chain of command decisions) that were imposed from the outside, or culturally foreign. These divergences are explained by several missteps throughout the reconstruction process:

1. A systemic failure of monitoring and oversight. UNAMET did not distinguish how transition would occur based on host-nation strengths and weaknesses. Instead, transition was implemented on a system wide scale with all institutions undergoing Timorization concurrently. The implementation of timelines, while critical to signify that the host-nation must take on responsibility, was overzealous in some respects when transferring authority. Especially in the 
management and oversight realms, Timorese institutions were not prepared to fully own responsibilities handed off by the UN. The host-nation should have been eased into responsibilities that were unfamiliar or lacking in capability. Timelines created to monitor responsibility handover should be analyzed through the moral obligation to withhold responsibility from individuals or institutions incapable of executing basic security functions.

2. Failure to recognize the appropriate role of the host nation in activities. The host-nation was able to make substantial progress in areas in which it was familiar or previously operating and used this experience to form local and provincial institutions. The approaches by which the host-nation succeeded were largely focused on bottom-up ownership and development rather than top-down initiatives handed out by the new government. Especially for the police force, local units that were established in advance of UN intervention were more successful at gaining the trust of the population and introducing new norms in the rule of law. Of course, some tradeoffs were required at the local level; security forces sometimes failed to abide by human rights and democratic standards for the sake of ensuring stability. However, the positive impact made by the host nation in developing truly organic and working institutions was ignored by international members who failed to incorporate these methods into the broader stabilization plan. 
3. Lack of appropriate civil society input in decisions. Civil society groups were largely left to operate on their own and did not coincide with activities undertaken by the central government. Instead, civil society groups forged their own initiatives to create stability in rural areas throughout the country. The help of civil society groups created vetting structures to oversee the work of local institutions, including some police units. This expertise would have added cultural nuance and character to international objectives for peace and stability.

4. Strategic goals reflected international, rather than local, ideals. Strategic goals focused on international approval and western models of governance. To worsen the situation, the lack of mentorship at the national and international levels did little to assimilate the host-nation with the rules, structures, and institutions by which it was required to abide. The structures and procedures put in place at the national level were often viewed as foreign by many of the Timorese who participated in SSR. A series of incongruent and inappropriate strategic goals further instigated many of the planning problems apparent in the Timorese mission. The effects of these goals have long-term implications, especially since they are embedded in laws, practices, and procedures used by the Timorese today.

5. Insufficient mentoring to recruit, train, and develop the right people. Many Timorese officials in central government positions originated from 
diaspora or elite communities and this noted difference with the population caused them to be ostracized by the community and sometimes other government officials. Little opportunity for mentorship was available to develop these capable personnel to operate effectively in the government. International oversight and mentorship at the federal level was lacking since most UNAMET and CIVPOL resources focused exclusively on community level training-an area the Timorese were more than ready to handle-rather than areas lacking in national and technical levels. UN and international mentors could have impacted the security sector by engaging with senior officials and politicians to handle political issues and refine the central government focus of SSR. Increased technical capabilities would have also contributed in many international goals.

A delicate balance must be found in weighing decisions over proper host-nation involvement in SSR with standards expected by the UN and international actors. Careful assessments, intimate communication with and participation of the host-nation, and cohesive goals may all contribute to delegating appropriate activities among actors to ensure successful SSR. Most importantly, actors engaging in security transitions must remember that transition is only successful if the host-nation is mentored and guided appropriately to allow it the opportunity for internal reflection and recalibration of its own goals and programs. 


\section{ENDNOTES}

1. This study adopts a narrow view of the 'security sector,' centered on the state's core security actors: military, police, and their civilian administrative bodies (ministries). A narrow, statecentric view focuses on the domestic institutions responsible for external and internal security and their civilian administrative bodies responsible for management and oversight. Wider views incorporate systems of justice, civil-society organizations, and some non-state actors who participate directly or indirectly in security provision. See Hänggi, Heiner (2009), "Security sector reform," in V. Chetail, ed., Postconflict Peacebuilding, Oxford, England; New York, NY: Oxford University Press; Hänggi, Heiner (2004), "Conceptualising security sector reform and reconstruction," in A. Bryden \& H. Hänggi, eds., Reform and Reconstruction of the Security Sector, Geneva, Switzerland: LIT Verlag; Geneva Centre for the Democratic Control of Armed Forces (DCAF).

2. See: Ball, Nicole (2005), "Strengthening democratic governance of the security sector in conflict-affected countries," Public Administration and Development Vol. 25, No. 1; Hänggi, Heiner (2009), "Security sector reform," in V. Chetail, ed., Postconflict Peacebuilding, Oxford, England; New York, NY: Oxford University Press; McFate, Sean (2008), Securing the Future: A Primer on Security Sector Reform in Conflict Countries, Washington, DC: U.S. Institute of Peace.

3. The term 'postconflict' refers to "the period when levels of insecurity are high; when violence is pervasive; when institutions are rudimentary, weak or non-existent; and when the very distinction between war and peace is blurred." See: Berdal, Mats R. (2009), Building Peace After War, New York, NY; London, England: Routledge, p. 20.

4. Brzoska, Michael and Andreas Heinemann-Gruder (2004), "Security sector reform and postconflict reconstruction under international auspices," in A. Bryden \& H. Hänggi, eds., Reform and Reconstruction of the Security Sector, Geneva, Switzerland: LIT Verlag. Wider views incorporate systems of justice, civil-society organizations, and some non-state actors who participate directly or indirectly in security provision. See Hänggi (2009), "Security sector reform"; Hänggi, Heiner (2004), "Conceptualising security 
sector reform and reconstruction," in A. Bryden \& H. Hänggi, eds., Reform and Reconstruction of the Security Sector, Geneva, Switzerland: LIT Verlag; Geneva Centre for the Democratic Control of Armed Forces (DCAF).

5. Of the 20 postconflict interventions since 1989, experts point to Sierra Leone as the only case having achieved some limited success in SSR, transferring programs to local control within three years. See for example, Paul Jackson, "SSR and Post-Conflict Reconstruction: The Armed Wing of State Building?," in The Future of Security Sector Reform, ed. Mark Sedra (Waterloo, Ontario, Canada: The Centre for International Governance Innovation, 2010); Mark Sedra, ed. The Future of Security Sector Reform (Waterloo, Ontario, Canada: The Centre for International Governance Innovation, 2010); Michael Brzoska and David Law, eds., Security Sector Reconstruction and Reform in Peace Support Operations (Abingdon, UK; New York, NY: Routledge, 2007).

6. By rejecting the offer, the Timorese expressed their desire for self-determination.

7. Between October 25, 1999 and May 20, 2002, the UN operated in Timor-Leste through United Nations Transitional Administration in East Timor (UNTAET). Operating under Security Council Resolution 1727 (1999) UNTAET was an integrated, multidimensional peacekeeping operation that held over responsibility for the administration of Timor-Leste as it sought to transition to independence. When Timor-Leste became independent, a new mission was created-United Nations Mission of Support in East Timor (UNMISET), operating under Security Council 1410 (2002). It was mandated to provide assistance to the newly formed government of Timor-Leste; provide interim law enforcement and security; and contribute to the internal and external security of the new country. On May 20, 2006, the Council established the United Nations Office in Timor-Leste (UNOTIL) operating under Security Council 1599 (2005) aimed at further developing the police; supporting the development of the Border Patrol Unit, and engaging in other technical assistance.

8. This occurred on September 12, 1999, when the Indonesian government accepted the deployment of INTERFET. 
9. United Nations Security Council (Aug 1999), Question of East Timor: Report of the Secretary-General (S/1999/862), New York, NY: United Nations. p. 2.

10. The UN Civilian Police component focused on building the capacity to maintain public law and order as a supporting mechanism to the new government. The forces were trained to preempt violence associated with the upcoming elections and movements to stymie the new political process.

11. The number of police trained by 2003 demonstrated Timor-Leste's progress in create a security structure for internal problems. The UN used these numbers as metrics of success. See: United Nations Security Council (July 2001), Progress Report of the Secretary-General on the United Nations Transitional Administration in East Timor, New York, NY: United Nations. p. 10-11.

12. Siapno, Jacqueline (2008), “Whispered confidences: Articulating the female in the PNTL (police) and the F-FDTL (military) in Timor-Leste," IIAS Newsletter, No. 48. p. 7.

13. Wilson, Bu Vicki Elizabeth (2010), Smoke and Mirrors: The Development of the East Timorese Police (1999-2009). p. 84.

14. There is no mention of a defense force in any of the UN mandates for the initial or follow-up missions.

15. United Nations (Jan 2001).

16. Ibid.

17. Ibid.

18. These factors are explained further in: U.S. Institute of Peace (USIP), and U.S. Army Peacekeeping \& Stability Operations Institute (PKSOI) (2009), Guiding Principles for Stabilization and Reconstruction, Washington, DC. p. 6-39:6-40.

19. U.S. Institute of Peace (USIP) and U.S. Army Peacekeeping and Stability Operations Institute (PKSOI) (2009). p. 1-3.

20. SSR functions courtesy of: U.S. Institute of Peace (USIP), and U.S. Army Peacekeeping and Stability Operations Institute (PKSOI) (2009), Guiding Principles for Stabilization and Reconstruction, Washington, D.C. p. 6-51:6-53. 
21. See for example the different ways that peacebuilding is understood and defined. Barnett, Michael, Hunjoon Kim, Madalene O'Donnell and Laura Sitea, "Peacebuilding: What is in a Name?" Global Governance, Vol. 13, No. 1 (2007), pp. 35-58.

22. Andrew Goldsmith, who conducted 44 interviews with Australian policing personnel who served in East Timor between May 28 and December 1, 2006, highlights this as his study points to major ontological challenges that the Australian police officers faced during their deployment. See also: Goldsmith, Andrew (2009), "'It wasn't like normal policing': Voices of Australian police peacekeepers in Operation Serene, Timor-Leste 2006," Policing and Society, Vol. 19, No. 2, pp. 119-133.

23. See for example: Paris, Ronald (2010), "Saving the liberal peace," Review of International Studies, Vol. 36, No. 2, pp. 337-365; Mac Ginty, Roger (2010), "Warlords and the liberal peace: State building in Afghanistan," Conflict, Security \& Development, Vol. 10, No. 4, pp. 577-598.

24. Wilson, Bu V.E. (2007), "Challenges to sustainable policebuilding: The development of the Policia Nacional Timor-Leste," in L. Palmer, S. Niner, \& L. Kent, eds., SSEE Research Paper No. 1/2007, Exploring the Tensions of Nation Building in Timor-Leste, Melbourne, Australia: University of Melbourne. p. 51.

25. Jones, Lee (2010), "(Post-)colonial State-building and State Failure in East Timor: Bringing Social Conflict Back In," Conflict, Security \& Development, Vol. 10, No. 4, pp. 547-575.

26. Chopra, Jarat (2002), "Building State Failure in East Timor," Development and Change, Vol. 33, No. 5 (2002), p. 985.

27. UN S.C. Res. 1272 (October 25, 1999).

28. Beauvais, Joel C. (2001) "Benevolent Despotism: A Critique of Un State-Building In East Timor," New York University Journal of International Law and Politics, Vol. 3, pp. 1101-1178.

29. Hood, Ludovic (2006), "Security sector reform in East Timor, 1999-2004," International Peacekeeping, Vol. 13, No. 1. p. 667.

30. Hood, Ludovic, (2006), "Security Sector Reform in East Timor, 1999-2004," Vol. 13, No. , p. 66. 
31. Dili Office (2009), Timor-Leste: No Time for Complacency, Asia Briefing No. 87, Dili, Timor-Leste; Brussels, Belgium: International Crisis Group. p. 6.

32. West, Ronald A. (2007), "Lawyers, guns and money: Justice and security reform in East Timor," in C. T. Call, ed., Constructing Justice and Security After War, Washington, DC: United States Institute of Peace Press. p. 331-332.

33. U.S. Agency for International Development (USAID) and Asia Foundation (2004), Law and Justice in East Timor: A Survey of Citizen Awareness and Attitudes Regarding Law and Justice in East Timor, Dili, Timor-Leste: The Asia Foundation. p. 40.

34. Lemay-Hebert, Nicolas (June 2009), "UNPOL and police reform in Timor-Leste: Accomplishments and setbacks," International Peacekeeping, Vol. 16, No. 3. p. 400.

35. West, Ronald A. (2007). p. 319.

36. Dili Office (2009), Handing Back Responsibility to TimorLeste's Police, Asia Report No. 180, Dili, Timor-Leste; Brussels, Belgium: International Crisis Group. p. 12.

37. Hood, Ludovic (2006), "Security sector reform in East Timor, 1999-2004." p. 146.

38. FRETILIN was considered a primary actor in encouraging the Indonesian government to grant the state independence.

39. Lemay-Hebert, Nicolas (June 2009). p. 395.

40. This assessment is derived from individual accounts collected from the resources cited in this document.

41. Dili Office (2009), Handing Back Responsibility to TimorLeste's Police. p.16.

42. Dili Office (2009), Timor-Leste: No Time for Complacency. p. 5.

43. Peake, Gordon (2009), "A lot of talk but not a lot of action: The difficulty of implementing SSR in Timor-Leste," in H. Born \& A. Schnabel, eds., Security Sector Reform in Challenging Environments, Geneva, Switzerland: Geneva Centre for the Democratic Control of Armed Forces. p. 230. 
44. Indonesian occupation allowed rural communities to oversee their own internal security concerns. Most policing functions were traditionally handled by elders or leaders in communities, rather than centralized security forces.

45. Wilson, Bu V.E. (2010), Smoke and Mirrors: The Development of the East Timorese Police (1999-2009). p. 70.

46. West, Ronald A. (2007). p. 331.

47. Funaki, Yoshino (2009), The UN and Security Sector Reform in Timor-Leste: A Widening Credibility Gap, New York, NY: Center on International Cooperation, New York University. p. 4.

48. Della-Giacoma, Jim (Jan 27-28, 2010), "Police building in Timor-Leste-mission impossible?" presented at GRIPS StateBuilding Workshop 2010: Organizing Police Forces in Postconflict Peace-Support Operations, GRIPS Police Research Center. p. 9-10.

49. Funaki, Yoshino (2009). p. 4.

50. Della-Giacoma, Jim (Jan 27-28, 2010). p. 5.

51. United Nations (2003), Joint Assessment Mission: Report of the Joint Assessment Mission Carried Out by the Government of TimorLeste, UNMISET, UNDP and Development Partner Countries for the Timor-Leste Police Service, New York, NY: United Nations. p. 15

52. Smith, M. and M. Dee (2006), "East Timor," in W.J. Durch, ed., 21st Century Peace Operations, Washington, DC: USIP Press Books. p. 445.

53. Funaki, Yoshino (2009). p. 4.

54. Lothe, Elisabeth and Gordon Peake (2010), "Addressing symptoms but not causes: Stabilisation and humanitarian action in Timor-Leste," Disasters, Vol. 34, No. 3. p. S436.

55. United Nations (2009), "Audit report: Management of the security sector support programme in UNMIT," Assignment No. AP2009/682/02, New York, NY: UN Office of Internal Oversight Services, Internal Audit Division. Executive summary.

56. Wainwright, Elsina (2002), New Neighbour, New Challenge: Australia and the Security of East Timor, Barton, Australia: Australian Strategic Policy Institute. p. 22. 
57. Human Rights Watch (2006), Tortured Beginnings: Police Violence and the Beginnings of Impunity in East Timor, Vol. 18, No. 2, New York: Human Rights Watch. p. 14.

58. Bowles, Edith and Tanja Chopra (2008), "East Timor: Statebuilding revisited," in C. Call \& V. Wyeth, eds., Building States to Build Peace, Lynne Rienner Publishers. p. 283.

59. Ibid. p. 277.

60. Hood, Ludovic (2006), "Security sector reform in East Timor, 1999-2004." p. 152.

61. International Center for Transitional Justice (June 2009), Security Sector Reform in Timor-Leste, IFP Security Cluster Country Case Study, Brussels, Belgium: Initiative for Peacebuilding. p. 11.

62. Conflict Security \& Development Group (2003). p. 155-56.

63. Traditionally, the police have more interaction with the public because they are focused on internal security. In comparison, the military tends to focus on external issues and thus trains away from the populace.

64. Funaki, Yoshino (2009). p. 5.

65. Ibid. p. 3.

66. This refers to a force that adheres entirely to international standards and composition as outlined by the organization, rather than the host-nation.

67. Bowles, Edith and Tanja Chopra (2008). p. 272.

68. International Center for Transitional Justice (June 2009). p. 13.

69. The Center for International Governance Innovation (May 2010), "Timor-Leste," Security Sector Reform Monitor Vol. 2. p. 6.

70. Chesterman, Simon (May 2001), East Timor in Transition: From Conflict Prevention to State-Building, New York, NY: International Peace Institute. p. 3. 
71. Wilson, Bu V.E. (2010), "To 2012 and beyond: International assistance to police and security sector development in TimorLeste," SSRC Conflict Prevention and Peace Forum, New York, NY. p. 7.

72. "Whole of security sector reform" refers to all institutions involved in security, not just the police and defense forces. Security institutions also include personnel management, financing, and technological expertise, among others.

73. Wilson, Bu V.E. (2010), Smoke and Mirrors: The Development of the East Timorese Police (1999-2009). p. 77.

74. Hood, Ludovic (2006), "Missed opportunities: The United Nations, police service and defence force development in TimorLeste, 1999-2004," Civil Wars, Vol. 8, No. 2. p. 144.

75. Smith, M. and M. Dee (2006). p. 445.

76. Dili Office (2008), Timor-Leste: Security Sector Reform, Asia Report No. 143, Dili, Timor-Leste; Brussels, Belgium: International Crisis Group. p. 9.

77. Dili Office (2009), Handing Back Responsibility to TimorLeste's Police. p. 19.

78. International Center for Transitional Justice (June 2009). p. 11.

79. Dili Office (2009), Timor-Leste: No Time for Complacency. p. 5.

80. United Nations (2003). p. 5.

81. Maley, William (2006), "International force and political reconstruction: Cambodia, East Timor, and Afghanistan," in A. Schnabel \& Hans-Georg Ehrhart, eds., Security Sector Reform and Postconflict Peacebuilding, New York, NY: United Nations University Press. p. 304.

82. Conflict Security \& Development Group (2003). p. 155-56.

83. Funaki, Yoshino (2009). p. 4.

84. Dili Office (2008). p. 9. 
85. The Center for International Governance Innovation (2009), "Timor-Leste," Security Sector Reform Monitor, Vol. 1. p. 6.

86. "Shadow government" refers to an organization that takes over activities that are usually associated with government control. Shadow governments are not elected by the populace but rather emerge to fill needs not being filled by the central system or emerge to competing with authorities.

87. Dili Office (2008), Timor-Leste: Security Sector Reform. p. 14.

88. The Center for International Governance Innovation (Dec 2001), "Handing back responsibility to Timor-Leste's police," Security Sector Reform Monitor, Vol. 1. p. 22.

89. Bowles, Edith and Tanja Chopra (2008). p. 283.

90. La'o Hamutuk (May 2003), "UNMISET and internal security in East Timor," The La'o Hamutuk Bulletin Vol. 4, No. 2. p. 6.

91. Smith, M. and M. Dee (2006). p. 440. 


\section{REFERENCES}

Armstrong, Nicholas J. and Jacqueline Chura-Beaver (2010), Harnessing Postconflict Transitions: A Conceptual Primer, Carlisle Barracks, PA: Strategic Studies Institute.

Ball, Nicole (2005), "Strengthening democratic governance of the security sector in conflict-affected countries," Public Administration and Development Vol. 25, No. 1.

Barnett, Michael, Hunjoon Kim, Madalene O'Donnell and Laura Sitea (2007), "Peacebuilding: What is in a Name?" Global Governance, Vol. 13, No. 1, pp. 35-58.

Beauvais, Joel C. (2001), “Benevolent Despotism: A Critique of Un State-Building In East Timor," New York University Journal of International Law and Politics, Vol. 3, pp. 1101-1178.

Berdal, Mats R. (2009), Building Peace After War, New York, NY; London, England: Routledge.

Bowles, Edith and Tanja Chopra (2008), "East Timor: Statebuilding revisited," in C. Call \& V. Wyeth, eds., Building States to Build Peace, Lynne Rienner Publishers. pp. 271-302.

Brzoska, Michael and Andreas Heinemann-Gruder (2004), "Security sector reform and postconflict reconstruction under international auspices," in A. Bryden \& H. Hänggi, eds., Reform and Reconstruction of the Security Sector, Geneva, Switzerland: LIT Verlag.

Brzoska, Michael and David Law, eds. (2007), Security Sector Reconstruction and Reform in Peace Support Operations (Abingdon, UK; New York, NY: Routledge).

The Center for International Governance Innovation (Dec 2001), "Handing back responsibility to Timor-Leste's police," Security Sector Reform Monitor, Vol. 1.

The Center for International Governance Innovation (2009), "Timor-Leste," Security Sector Reform Monitor, Vol. 1.

The Center for International Governance Innovation (May 2010), "Timor-Leste," Security Sector Reform Monitor, Vol. 2. 
Chesterman, Simon (May 2001), East Timor in Transition: From Conflict Prevention to Statebuilding, New York, NY: International Peace Institute.

Chinn, Liam (2009), Community Policing in Timor-Leste, San Francisco, CA: The Asia Foundation.

Conflict Security \& Development Group (2003), A Review of Peace Operations: A Case for Change (East Timor), London, England: Kings College.

Da Costa, Lucas \& Jose Antonio Neves (2001), A Popular Challenge to UNTAET's Achievements, Dili, Timor-Leste: Asia Pacific Support Collective.

Della-Giacoma, Jim (Jan 2010), "Police building in Timor-Lestemission impossible?" presented at GRIPS Statebuilding Workshop 2010: Organizing Police Forces in Postconflict Peace-Support Operations, GRIPS Police Research Center.

Dili Office (2008), Timor-Leste: Security Sector Reform, Asia Report No. 143, Dili, Timor-Leste; Brussels, Belgium: International Crisis Group.

Dili Office (2009), Handing Back Responsibility to Timor-Leste's Police, Asia Report No. 180, Dili, Timor-Leste; Brussels, Belgium: International Crisis Group.

Dili Office (2009), Timor-Leste: No Time for Complacency, Asia Briefing No. 87, Dili, Timor-Leste; Brussels, Belgium: International Crisis Group.

Funaki, Yoshino (2009), The UN and Security Sector Reform in Timor-Leste: A Widening Credibility Gap, New York, NY: Center on International Cooperation.

Goldsmith, Andrew (2009), "'It wasn't like normal policing': Voices of Australian police peacekeepers in Operation Serene, Timor-Leste 2006," Policing and Society, Vol. 19, No. 2, pp. 119133.

Hänggi, Heiner (2004), "Conceptualising security sector reform and reconstruction," in A. Bryden \& H. Hänggi, eds., Reform and Reconstruction of the Security Sector, Geneva, Switzerland: 
LIT Verlag; Geneva Centre for the Democratic Control of Armed Forces (DCAF).

Hänggi, Heiner (2009), "Security sector reform," in V. Chetail, ed., Postconflict Peacebuilding, Oxford, England; New York, NY: Oxford University Press; Hänggi, Heiner (2004).

Hood, Ludovic (2006), "Missed opportunities: The United Nations, police service and defence force development in TimorLeste, 1999-2004," Civil Wars, Vol. 8, No. 2. pp. 143-162.

Hood, Ludovic (2006), "Security sector reform in East Timor, 1999-2004," International Peacekeeping, Vol. 13, No. 1. pp.60-71.

Human Rights Watch (2006), Tortured Beginnings: Police Violence and the Beginnings of Impunity in East Timor, Vol. 18, No. 2, New York: Human Rights Watch.

International Center for Transitional Justice (June 2009), Security Sector Reform in Timor-Leste, IFP Security Cluster Country Case Study, Brussels, Belgium: Initiative for Peacebuilding.

Jackson, Paul (2010), "SSR and Post-Conflict Reconstruction: The Armed Wing of State Building?," in Mark Sedra (ed.), The Future of Security Sector Reform, Waterloo, Ontario, Canada: The Centre for International Governance Innovation.

Jones, Lee (2010), "(Post-)colonial State-building and State Failure in East Timor: Bringing Social Conflict Back In," Conflict, Security \& Development, Vol. 10, No. 4, pp. 547-575.

Sedra, Mark (ed.) (2010), The Future of Security Sector Reform, Waterloo, Ontario, Canada: The Centre for International Governance Innovation.

La'o Hamutuk (May 2003), "UNMISET and internal security in East Timor," The La'o Hamutuk Bulletin Vol. 4, No. 2.

Lemay-Hebert, Nicolas (June 2009), "UNPOL and police reform in Timor-Leste: Accomplishments and setbacks," International Peacekeeping, Vol. 16, No. 3. pp. 393-496.

Lothe, Elisabeth and Gordon Peake (2010), "Addressing symptoms but not causes: Stabilisation and humanitarian action in Timor-Leste," Disasters, Vol. 34, No. 3. pp. S427-S443. 
McFate, Sean (2008), Securing the Future: A Primer on Security Sector Reform in Conflict Countries, Washington, DC: U.S. Institute of Peace.

MacGinty, Roger (2010), "Warlords and the liberal peace: State building in Afghanistan," Conflict, Security \& Development, Vol. 10, No. 4. pp. 577-598.

Maley, William (2006), "International force and political reconstruction: Cambodia, East Timor, and Afghanistan," in A. Schnabel \& Hans-Georg Ehrhart, eds., Security Sector Reform and Postconflict Peacebuilding, New York, NY: United Nations University Press. pp. 297-312.

Myrttinen, Henri (2009), Poster Boys No More: Gender and Security Sector Reform in Timor-Leste, Geneva, Switzerland: Geneva Centre for the Democratic Control of Armed Forces (DCAF).

Myrttinen, Henri (2009), "Timor-Leste: A relapsing "success" story," Taiwan Journal of Democracy, Vol. 5, No. 1. pp. 219-239.

Paris, Ronald (2010), "Saving the liberal peace," Review of International Studies, Vol. 36, No. 2. pp. 337-365.

Peake, Gordon (2009), "A lot of talk but not a lot of action: The difficulty of implementing SSR in Timor-Leste," in H. Born \& A. Schnabel, eds., Security Sector Reform in Challenging Environments, Geneva, Switzerland: Geneva Centre for the Democratic Control of Armed Forces. pp. 213-238.

Siapno, Jacqueline (2008), “Whispered confidences: Articulating the female in the PNTL (police) and the F-FDTL (military) in Timor-Leste," IIAS Newsletter, No. 48. pp. 7-8.

Smith, M. and M. Dee (2006), "East Timor," in W.J. Durch, ed., 21st Century Peace Operations, Washington, DC: USIP Press Books. pp. 389-466.

U.S. Agency for International Development (USAID) and Asia Foundation (2004), Law and Justice in East Timor: A Survey of Citizen Awareness and Attitudes Regarding Law and Justice in East Timor, Dili, Timor-Leste: The Asia Foundation. 
United Nations (Jan 2001), Report of the Secretary-General on the United Nations Transitional Administration in East Timor (for the period 27 July 2000 to 16 January 2001), New York, NY: United Nations.

United Nations (2003), Joint Assessment Mission: Report of the Joint Assessment Mission Carried Out by the Government of TimorLeste, UNMISET, UNDP and Development Partner Countries for the Timor-Leste Police Service, New York, NY: United Nations.

United Nations (2009), “Audit report: Management of the security sector support programme in UNMIT," Assignment No. AP2009/682/02, New York, NY: UN Office of Internal Oversight Services, Internal Audit Division.

United Nations Security Council (Aug 1999), Question of East Timor: Report of the Secretary-General (S/1999/862), New York, NY: United Nations.

United Nations Security Council (July 2001), Progress Report of the Secretary-General on the United Nations Transitional Administration in East Timor, New York, NY: United Nations.

U.S. Institute of Peace (USIP), and U.S. Army Peacekeeping \& Stability Operations Institute (PKSOI) (2009), Guiding Principles for Stabilization and Reconstruction, Washington, D.C.

Wainwright, Elsina (2002), New Neighbour, New Challenge: Australia and the Security of East Timor, Barton, Australia: Australian Strategic Policy Institute.

West, Ronald A. (2007), "Lawyers, guns and money: Justice and security reform in East Timor," in C. T. Call, ed., Constructing Justice and Security After War, Washington, DC: United States Institute of Peace Press. pp. 313-350.

Wilson, Bu V.E. (2007), "Challenges to sustainable police-building: The development of the Policia Nacional Timor-Leste," in L. Palmer, S. Niner, \& L. Kent, eds., SSEE Research Paper No. 1/2007, Exploring the Tensions of Nation Building in Timor-Leste, Melbourne, Australia: University of Melborne. pp. 49-58.

Wilson, Bu V.E. (2010), Smoke and Mirrors: The Development of the East Timorese Police (1999-2009), Canberra, Australia: Australian National University. 
Wilson, Bu V.E. (2010), "To 2012 and beyond: International assistance to police and security sector development in TimorLeste," SSRC Conflict Prevention and Peace Forum, New York, NY. 


\title{
U.S. ARMY WAR COLLEGE
}

\author{
Major General Gregg F. Martin \\ Commandant
}

\section{***** \\ PEACEKEEPING \& STABILITY OPERATIONS INSTITUTE}

\author{
Director \\ Colonel Cliff D. Crofford
}

\author{
Deputy Director \\ COL Lorelei E. Coplen
}
Author
Nicholas J. Armstrong
Jacqueline Chura-Beaver
Issac Kfir

Chief, Research and Publications

Ms. Karen Finkenbinder

Publications Coordinator

Mr. R. Christopher Browne

*****

Composition

Mrs. Jennifer E. Nevil 
